\title{
WStabilization of Expansive Soil using Dolochar and Lime
}

\author{
Soumendra Kumar Mohanty* \\ Civil Engineering, SM Consultants, India \\ *Corresponding author: Soumendra Kumar Mohanty, Civil Engineering MD, SM Consultants

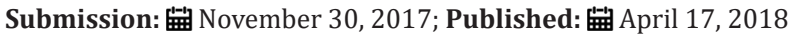

\begin{abstract}
An experimental investigation is carried out to study the stabilization of local expansive soil by using dolochar and lime. Dolochar is added to the expansive soil from $5 \%$ to $30 \%$ by weight of total dry soil mixture with an increment of $5 \%$. The geo-technical properties such as consistency, swelling, compaction and strength characteristic like California bearing ratio (CBR) of stabilized soil are studied. From the above study, the optimum dolochar content is found to be $30 \%$. The lime (quick lime) is then added at low percentages i.e., $1 \%$ to $5 \%$ with an increment of $1 \%$ to the optimum soil-dolochar mixture. The mixed samples (soil-dolochar-lime) are soaked for 4, 7, 14, 21, 28 and 56 days to determine the CBR values. From the test results, it is seen that the maximum strength is achieved at the proportion of 70:30:4 for the soil-dolochar-lime mixture samples. The 4 days soaked CBR at 30\% dolochar and $4 \%$ lime content of the expansive soil is increased by $672 \%$ as compared to soil alone. Further, it is observed that the concentrations of heavy metals leached from the stabilized soil with optimum mixture are found to be within the acceptable limits.
\end{abstract}

Keywords: California bearing ratio; Dolochar; Free swell index; Leachate characteristics; Lime; Stabilization

\section{Introduction}

The expansive soil undergoes volumetric changes due to the variation of its water content. The fine particles $(<75 \mu)$ present in the expansive soil have responsible for the water holding capacity. Further, due to the seasonal variation, the presence of water content in the expansive soil varies. The expansive soil undergoes swelling on wetting resulting loss of strength and shrinking on drying leading to the development of shrinkage cracks. The swelling and shrinkage characteristics of the expansive soil causes the differential movements resulting in severe damage to the foundations, buildings, roads, retaining structures, canal linings, etc. It has always been a great challenge for geo-technical engineers to improve the engineering properties of expansive soil through various innovative and cost effective techniques. Stabilization of expansive soil using various additives is one among them.

The industrial wastes namely, fly ash, dolochar, ground granulated blast-furnace slag (GGBS) and etc is generated from various industries in the state of Odisha. The industries are generally dumped the industrial wastes in their vicinity causing environmental hazards. Hence, there is an urgent need to explore the use of the above industrial wastes minimizing the environmental hazards. The review of literature reveals that a good number of research works have been carried out for stabilizing the expansive soils by using various industrial wastes via, fly ash, cement kiln dust, lime kiln dust, GGBS, rice husk ash, iron ore tailing, etc. [1-14]. Many others have studied the improvement of various engineering properties of expansive soil on addition of industrial wastes and lime.
They have shown that industrial wastes with lime can be useful additives to the expansive soil. In the present study an attempt has been made to study the stabilization of locally available expansive soils by using dolochar (industrial waste) with or without lime, which can satisfactorily be used for the construction of road, pavements, foundation, etc. The expansive soil and dolochar are collected from the Balasore, district of the state of Odisha, India, whereas lime (quick lime) is collected from the local market.

\section{Experimental Programme}

A detail experimental programme is prepared to study the geotechnical characteristics of soil stabilized by dolochar with and without the addition of lime. The soil-dolochar mixture samples are prepared by adding the dolochar to the parent soil separately with an increment of $5 \%$ by wt. of dry soil mixture from 5 to $30 \%$, whereas soil-dolochar-lime samples are prepared by adding the lime to the $70 \%$ soil $+30 \%$ dolochar mixture sample from 1 to $5 \%$ by dry wt. of the mixture with an increment of $1 \%$. All the stabilized samples are tested in the laboratory to study the consistency, swelling, compaction and strength characteristics (CBR). The stabilized soils (optimum mixture) are also tested to study its leaching potential in order to ascertain the sustainability of the stabilization method adopted.

\section{Results and Discussions}

From the test, it is revealed that the consistency and swelling characteristic of soil-dolochar and soil-dolochar-lime samples 
are decreased with the increase of dolochar and lime content respectively whereas, the maximum dry density (MDD) of soildolohar and soil-dolochar-lime samples are increased with the increase of dolochar and lime content respectively. Strength characteristics such as California bearing ratio (CBR) of stabilized soils i.e., soil-dolochar and soil-dolochar-lime samples are increased with the increase of dolochar and lime content respectively. The effects of dolochar and lime on the CBR of the soil and soil-dolochar samples are presented at Figure $1 \& 2$.

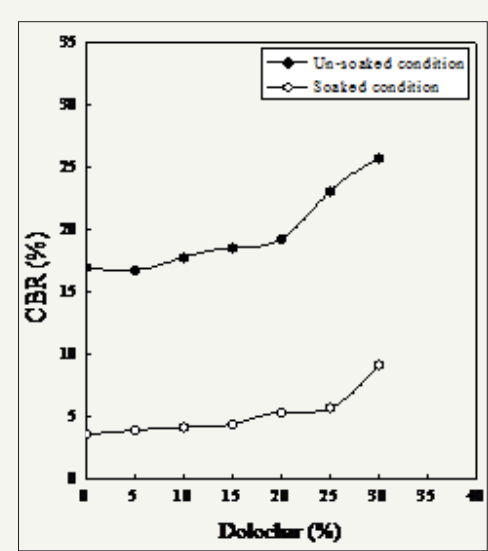

Figure 1: Effect of dolochar on the CBR of the expansive soil.



Figure 2: Effect of lime on the CBR at different soaking periods of soil - dolochar mixture.

The leaching properties of dolochar and stabilized materials namely soil-dolochar (70:30) and soil-dolochar-lime (70:30:4) are studied by column leaching tests and it is revealed that the concentrations of heavy metals leached from the soil mixtures are within the acceptable limits of drinking water as per IS 10500: 2012.

\section{Conclusion}

Based on the experimental investigation test results following conclusions are drawn.

a) With addition of dolochar, the consistency and swelling characteristics of soils gradually decreases with the increase of dolochar contents. Also, addition of lime to the soil-dolochar mixture reduces the consistency and swelling characteristics further. The free swell index of soil with 30\% dolochar and $5 \%$ lime content, it reduced by $85 \%$. At $30 \%$ dolochar content, the optimum moisture content decreases by $30 \%$ whereas, MDD increases by $15 \%$ for expansive soil. Addition of lime to the soil-dolochar mixture increases both OMC and MDD. CBR of soil-dolochar and soil-dolochar-lime samples increase with the increase of dolochar and lime content respectively. At 30\% dolochar content, the 4 days soaked CBR of local expansive soil increases by $163 \%$. With $30 \%$ dolochar and $4 \%$ lime content, the 4-days soaked CBR of expansive soil increase by $672 \%$ as compared to soil alone.

b) The optimum mixture design proportion of soil-dolocharlime is found to be 70:30:04 for the materials i.e., soil, dolochar, lime, etc taken for the studies in this case.

c) The concentrations of heavy metals leached from the stabilized soil with optimum mixture are found to be within the acceptable limits.

Addition of 30\% dolochar with $4 \%$ lime will definitely improve the local expansive soil for sustainable use in the construction of roads, pavements and foundations which will reduce the cost of construction and disposal problem of industrial wastes which otherwise lead to environmental hazards.

\section{References}

1. Cokca E (2001) Use of class C fly ashes for the stabilization-of an expansive soil. Journal of Geotechnical and Geo environmental Engineering 127: 568-573

2. Cetina B, Aydilek AH, Guney Y (2012) Leaching of trace metals from high carbon fly ash stabilized highway base layers. Resources Conservation and Recycling 58: 8-17.

3. Edil TB, Acosta HA, Benson CH (2006) Stabilizing soft fine grained soils with fly ash. Journal of Materials in Civil Engineering ASCE 18(2): 283294.

4. Etim RK, Osinubi KJ, Eberemu AO (2017) Stabilization of black cotton soil with lime and iron ore tailings admixture. Transportation Geotechnics 10: 85-95.

5. Goswami RK, Mahanta C (2007) Leaching characteristics of residual lateritic soils stabilized with fly ash and lime for geotechnical application Waste Manag 27(4): 466-481.

6. Hossain KMA, Mol L (2011) Some engineering properties of stabilized clayey soils incorporating natural pozzolans and industrial wastes. Construction and Building Materials 25(8): 3495-3501.

7. Kang X, Ge L, Kang G, Mathews C (2015) Laboratory investigation of the strength, stiffness, and thermal conductivity of fly ash and lime kiln dust stabilised clay subgrade materials. Road Materials and Pavement Design 16(4): 928-945.

8. Kate, JM (2009) Behavior of expansive clays treated with lime-fly ash admixtures. In Proc. Indian Geotechnical Conference, Guntur, India, pp. 88-91.

9. Kolay P, Ramesh K (2016) Reduction of expansive index, swelling and compression behavior of kaolinite and bentonite clay with sand and class C fly ash. Geotechnical and Geological Engineering 34(1): 87-101. 
10. Mir BA, Sridharan A (2014) Volume change behavior of clayey soil-fly ash mixtures. International Journalof Geotechnical Engineering 8(1): 72-83.

11. Phanikumar BR, Sharma R S (2004) Effect of fly ash on engineering properties of expansive soil. Journal of Geotechnical and Geo environmental Engineering 130(7): 764-767.

12. Sahoo JP, Sahoo S, Yadav VK (2010) Strength characteristics of fly ash mixed with lime stabilized soil. Indian Geotechnical Conference, pp. 429432
13. Sridharan A, Prashanth JP, Sivapullaiah PV (1997) Effect of fly ash on the unconfined strength of black cotton soil. Ground Improvement 1(3): 169-175.

14. Zha F, Liu S, Du Y, Cui K (2008) Behavior of expansive soils stabilized with fly ash. Natural Hazards 47(3): 509-523.
Creative Commons Attribution 4.0 International License

For possible submissions Click Here
Submit Article

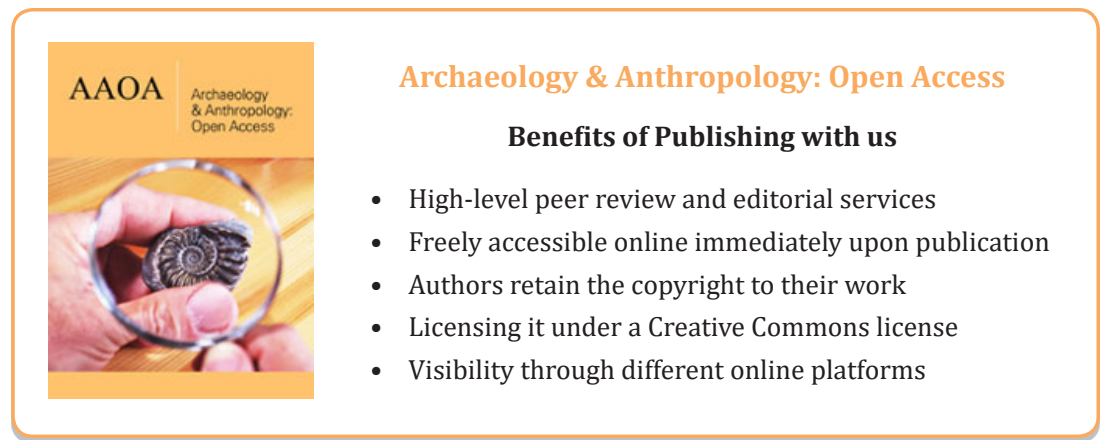

